\title{
Active Packaging of Button Mushrooms with Zeolite and Açai Extract as an Innovative Method of Extending Its Shelf Life
}

\author{
Monika Hanula *, Ewelina Pogorzelska-Nowicka, Grzegorz Pogorzelski, Arkadiusz Szpicer, \\ Iwona Wojtasik-Kalinowska, Agnieszka Wierzbicka and Andrzej Półtorak
}

\section{check for}

updates

Citation: Hanula, M.;

Pogorzelska-Nowicka, E.;

Pogorzelski, G.; Szpicer, A.;

Wojtasik-Kalinowska, I.; Wierzbicka,

A.; Półtorak, A. Active Packaging of

Button Mushrooms with Zeolite and Açai Extract as an Innovative Method of Extending Its Shelf Life. Agriculture 2021, 11, 653. https://doi.org/ 10.3390/agriculture 11070653

Academic Editor: María Gloria Lobo

Received: 8 June 2021

Accepted: 9 July 2021

Published: 11 July 2021

Publisher's Note: MDPI stays neutral with regard to jurisdictional claims in published maps and institutional affiliations.

Copyright: (c) 2021 by the authors. Licensee MDPI, Basel, Switzerland. This article is an open access article distributed under the terms and conditions of the Creative Commons Attribution (CC BY) license (https:// creativecommons.org/licenses/by/ $4.0 /)$.
Institute of Human Nutrition Sciences, Department of Technique and Food Product Development, Warsaw University of Life Sciences (WULS-SGGW), Nowoursynowska 159 c Street, 02-776 Warsaw, Poland; ewelina_pogorzelska@sggw.edu.pl (E.P.-N.); grzegorz_pogorzelski1@sggw.edu.pl (G.P.); arkadiusz_szpicer@sggw.edu.pl (A.S.); iwona_wojtasik_kalinowska@sggw.edu.pl (I.W.-K.); agnieszka_wierzbicka@sggw.edu.pl (A.W.); andrzej_poltorak@sggw.edu.pl (A.P.)

* Correspondence: monika_hanula@sggw.edu.pl

Abstract: As the market demand for button mushrooms is constantly growing, it is important to extend their shelf-life. Active packaging with built-in active components offers the possibility of extending the shelf life of products which are sensitive to external factors. Therefore, the aim of the present study was to check the effect of active packaging with zeolite (clinoptilolite) and açai extract on the bioactive compounds content, antioxidant activity, volatile compound profile, and physical quality of mushrooms subjected to storage for 28 days at $4{ }^{\circ} \mathrm{C}$. Packing mushrooms in active packages improved their chemical characteristics by increasing antioxidant activity $(p \leq 0.001)$ in comparison to the conventional packaging methods. Moreover, it slowed down water loss and the browning process both on the surface and inside the mushroom. Furthermore, the results showed a strong correlation $(p \leq 0.001)$ between antioxidant activity, bioactive compounds content and color parameters. The obtained results suggest that the addition of the açai extract and zeolite into packaging material protects mushrooms from deterioration for a longer period of time. The use of active packaging to extend product shelf life can contribute to the reduction of the use of food preservatives, but also protects the environment by reducing the volume of waste.

Keywords: antioxidant; nanocomposite; films; Agaricus bisporus; volatile compounds; malondialdehyde; clinoptilolite

\section{Introduction}

An extremely difficult challenge for humanity will become apparent in the coming decades in the context of environmental (as exhaustive source) protection. The increased demand for food enforces the language of consensus, where, on the one hand, there is a continuous increase in the population, and on the other, natural resources are limited. Furthermore, a huge amount of produced food is wasted. These losses account for a quarter of total global farmland and fertilizer use [1]. Taking into consideration the growing trend of food production, the amount of food wastage cannot be ignored. This is why it is so important to maintain an economic and ecological balance [1,2].

Considering the above, it is of high importance to extend shelf-life of food by applying new packaging methods. Active packaging has recently gained great popularity and is extensively studied worldwide [3]. This type of packaging "deliberately incorporates components that would release or absorb substances into or from the packaged food or the environment surrounding the food" [4]. According to these criteria, the ingredients incorporated to the food packages might be active compounds, extracts, mixtures, or components (especially nanomaterials or nanostructures) that exhibit unique properties (small size, high surface/volume ratio, quantum effects) [5]. 
Zeolites are considered safe for humans according to the Food and Drug Administration (FDA). Moreover, the International Agency for Research on Cancer (IARC) classified zeolites as non-toxic [6]. Zeolites are crystalline hydrated aluminosilicates, with a characteristic three-dimensional structure, obtained by cage or cavity bond connections. Therefore, they are classified as molecular sieves. This ability allows absorption and cation exchange of chemical compound molecules. Due to its water and ethylene absorption properties, zeolites have found application in various fields, especially in agriculture. Zeolites have been implemented as an active component of low-density polyethylene (LDPE) or high-density polyethylene (HDPE) films used for extending shelf-life of mangoes, kiwifruits, tomatoes, or broccoli $[6,7]$.

Bioactive compounds or plant extracts are an integral part of active packaging. In most cases, the ingredients used for the creation of active packaging have antioxidant properties (influencing oxidative stability improvement) or bactericidal or/and fungicidal. Producers following the new trend of replacing synthetic additives with natural ones, are looking for new bioactive compounds that might be used in active packaging. Tropical plants are of great interest to scientists because of their unexplored potential. One such plant is açai (Euterpe oleracea Mart.) from the Aracaceae family, the popularity of which has increased rapidly in recent years. Dark purple acai berries are known to be "superfood" because of their rich content of phytochemicals such as polyphenolic compounds (phenolic acids, ferulic acid, gallic, ellagic acid glycoside, vanillic), anthocyanins (kuromanin, cyanidin3 -glucoside, keracyanin), flavonoids (orientin), and volatile compounds [8,9]. Acai has been successfully used as an antimicrobial, anti-inflammatory, antioxidative, as well as a neuroprotective and cardioprotective agent [10]. Because of their medicinal properties, acai berries help to improve health.

Nowadays, there is a growing health consciousness among populations worldwide and a growing trend towards vegan food and natural foods in the diet. In turn, mushrooms have multiple health benefits and are a relevant component of those diets. Thus, the global mushroom market is projected to experience significant growth. The value of the mushroom cultivation market reached USD 16.7 billion in 2020 and is predicted to grow at a CAGR (compound annual growth rate) of 4.0\% to reach USD 20.4 billion on 2025 . As much as $40 \%$ of global mushroom production is button mushroom. Agaricus bisporus (white button mushrooms) is one of the most popular cultivated mushrooms species worldwide [11]. It is also relatively inexpensive in terms of cultivation, low in calories, and contains some vitamins and minerals (niacin, riboflavin, phosphorus, copper, zinc, magnesium). Moreover, white button mushrooms contain bioactive compounds, which exert antimutagenic, chemoprotective, and hypocholesterolemic activity. Furthermore, $A$. bisporus mushrooms are best known for their taste qualities. However, a negative aspect of this fungus is that it is very perishable, resulting in a short shelf life $[12,13]$.

Thus, it is extremely important to find a suitable form of packaging that will extend the shelf life of white button mushrooms, which will allow to reduce food wastage. According to our knowledge, the effect of active packaging with the addition of zeolite and açai extract on the quality of $A$. bisporus subjected to storage under cold conditions has not been studied.

\section{Materials and Methods}

\subsection{Preparation of Active Membranes}

The active packaging with açai extract, zeolite, and açai extract + zeolite was made by coating the packages by prepared solvent casting. First an açai extract was prepared. Briefly, $2 \mathrm{~g}$ of açai (superfoods, PL-EKO-07) was homogenized in $50 \mathrm{~mL}$ of $50 \%(v / v)$ ethanol for $2 \mathrm{~min}$ at $13,000 \mathrm{rpm}$. Then, extraction was performed using an ultrasound at $45^{\circ} \mathrm{C}$ for $5 \mathrm{~min}$. The extract was centrifuged, and supernatant stored at $4{ }^{\circ} \mathrm{C}$ until film preparation. Then, $6 \mathrm{~g}$ of gelatin and $12 \mathrm{~g}$ of glycerin were added to $100 \mathrm{~mL}$ of distilled water and mixed at $57^{\circ} \mathrm{C}$ for $30 \mathrm{~min}$ until gelatinous. Subsequently, we added $3 \mathrm{~g}$ of açai powder for the film with extract (FE), $1 \mathrm{~g}$ of zeolite for the film with zeolite (FZ), $1.5 \mathrm{~g}$ of açai extract, and $0.5 \mathrm{~g}$ 
of zeolite to $100 \mathrm{~mL}$ of the solution and magnetically agitated for $15 \mathrm{~min}$ at $40{ }^{\circ} \mathrm{C}$. Then, $50 \mathrm{~mL}$ of prepared solution was casted on a plastic PET tray $\left(9 \times 14 \mathrm{~cm}^{2}\right)$ and dried in a convection oven for $12 \mathrm{~h}$ at $45^{\circ} \mathrm{C}$.

\subsection{Packaging and Storage of Mushrooms}

Agaricus bisporus were grown at a cultivation farm in Wierzbno, Poland. Collected fruit bodies were characterized by even growth and surface area $(3-5 \mathrm{~cm}$ diameter of a mushroom cap). Harvested mushrooms were precooled at $4{ }^{\circ} \mathrm{C}$ and transported at the same day to the laboratory $\left(4^{\circ} \mathrm{C}\right)$. The mushrooms were divided into 5 groups. Three groups were packed with gel films enriched with bioactive components (FE or FZ or FEZ), one group was packed without gel film $(\mathrm{C})$, and the last one was packed also without gel film but was additionally wrapped with plasticized (PVC) foil. FE, FZ, FEZ, and C groups were packed in microperforated PSF film under modified atmosphere $\left(5 \% \mathrm{CO}_{2}, 80 \% \mathrm{O}_{2}\right.$, $15 \% \mathrm{~N}_{2}$ ) using Sealpac Traysealer M3 (Oldenburg, Germany). The microperforated foil had hole size of $143 \mu \mathrm{m}, 25 \mu \mathrm{m}$ thickness, and $\mathrm{O}_{2}$ transmission rate of $7000 \mathrm{~cm}^{3}$ day $^{-1}$ $0.1 \mathrm{MPa}^{-1}$. Packed mushrooms were kept in the fridge at $4{ }^{\circ} \mathrm{C}$ for 28 days. Chemical and physical analysis were performed on $0,7,14,21$, and 28 storage days.

\subsection{Physical Analysis of Mushrooms}

\subsubsection{Gas Composition}

$\mathrm{CO}_{2}$ and $\mathrm{O}_{2}$ (gas composition) analysis was measured using a gas analyzer (WittGasetechnik, Written, Germany). Measurements were carried out in triplicate.

\subsubsection{Physiological Weight Loss}

Weight loss was presented as percentage loss and calculated according to the following equation:

$$
\text { Weight Loss }(\%)=(\mathrm{W} 0-\mathrm{Ws}) / \mathrm{W} 0 \times 100
$$

where W0 is the weight mushrooms in day 0 and Ws is the weight after storage (day: 7, 14, $21,28)$.

Obtained results were averaged out of five replicates.

\subsubsection{Color Analysis \\ CIE L*a*b* Analysis}

The surface color of mushroom caps was measured in CIE $\mathrm{L}^{*} \mathrm{a}^{*} \mathrm{~b}^{*}$ system using Konica Minolta chromameter (CR400., Tokyo, Japan). The instrument was calibrated before measurements on the white standard plate. The area of single measurement was illuminated by a D65 light source. Analyses were performed in thirty replicates for each one experimental group. Proper calculations were made in order to estimate the browning index $(\mathrm{BI})$ and color change $(\Delta \mathrm{E})$ according to formulas described by Djekic et al. [14].

\section{Color Change of Mushroom Cap}

The browning area was measured on the cross-section of the mushroom along the axis of symmetry. Analysis was performed by computer image analysis using OImaging MicroPublisher 5.0 RTV (Canada) equipped with Kaiser system (Germany). Browning area was calculated using Image-Pro Plus software (v.7.0). The measurement was performed in eighteen replicates for each group, and the results were presented as the percentage of mushroom cap browning. The following equation was used for calculations:

$$
\text { Browning }(\%)=\mathrm{Pb} / \mathrm{Pc} \times 100
$$

where $\mathrm{Pb}$ is the brown surface of the mushrooms cap and $\mathrm{Pc}$ is the total surface area of the mushroom cap. 


\subsubsection{Texture Analysis}

The penetration test was performed on the mushroom caps using the Instron 5965 Universal Testing Machine (Instron. Norwood, MA, USA) equipped with a diameter cylindrical probe $(5 \mathrm{~mm})$. Penetration test was conducted puncturing to a depth of $8 \mathrm{~mm}$ inside the mushroom cap. The speed of the probe during penetration was $2 \mathrm{~mm} \mathrm{~s}^{-1}$. Firmness was defined as the maximum force recorded. Measurement was performed in eleven replicates.

\subsection{Chemical Analysis of Mushrooms}

\subsubsection{Mushroom Extraction for TPC, DPPH and FRAP Analysis}

Mushrooms on each storage day were cut and dried in convection oven (Seria FP Classic. Line, Model 115, BINDER) for $16 \mathrm{~h}$ at $45{ }^{\circ} \mathrm{C}$. The dry matter was then milled, and $1 \mathrm{~g}$ was weighted and homogenized with $9 \mathrm{~mL}$ of methanol. Then, the extract was subjected to ultrasound for $30 \mathrm{~min}$ at $35^{\circ} \mathrm{C}$. Further, extract was shaken for $15 \mathrm{~min}$ and centrifuged for $10 \mathrm{~min}$ at $9000 \mathrm{rpm}$ and $4{ }^{\circ} \mathrm{C}$. Obtained samples were then stored at $4{ }^{\circ} \mathrm{C}$ until the time of the analysis.

\subsubsection{Total Phenolic Compounds (TPC)}

The analysis of the content of total phenolic compounds was performed based on method of Singleton and Rossi [15] with minor modification. In brief, $0.250 \mathrm{~mL}$ of FolinCiocalteu's reagent, $2.5 \mathrm{~mL}$ of $7 \% \mathrm{Na}_{2} \mathrm{CO}_{3}, 3.4 \mathrm{~mL}$ of $\mathrm{H}_{2} \mathrm{O}$ were added to $0.1 \mathrm{~mL}$ of the extract and next shaken. The mixture was kept in the dark for $30 \mathrm{~min}$. After that, the absorbance was measured at $750 \mathrm{~nm}$ wavelength using UV-VIS spectrophotometer against the blank. TPC was expressed as mg of gallic acid equivalent per gram of dry weight $(\mathrm{mg} / \mathrm{g} \mathrm{dw})$.

\subsubsection{Vitamin C (L-Ascorbic Acid, Vitamin C) Content}

The analysis of the L-ascorbic acid content was conducted according to the method of Balogh and Szarka [16] with some minor modifications. Dried mushrooms powder $(1 \mathrm{~g})$ was mixed with $10 \mathrm{~mL}$ of $5 \%$ acetic acid and homogenized. After that the mixture was shaken for $30 \mathrm{~min}$ and the extract was centrifuged for $10 \mathrm{~min}$, at $9000 \mathrm{rpm}\left(4^{\circ} \mathrm{C}\right)$ and filtrated. Afterwards, the extract was mixed with $1 \%$ 2,2'-bipyridyl, $0.1 \% \mathrm{FeCl} 3$, and $85 \%$ orthophosphoric acid and subjected to $5 \mathrm{~min}$ incubation in dark room. After that, the absorbance was measured at $525 \mathrm{~nm}$ using a UV-VIS spectrophotometer against the blank. Vitamin C content was expressed as ascorbic acid $\mathrm{mg} / \mathrm{g} \mathrm{dw}$.

\subsubsection{Malonylodialdehyd (MDA) Content}

The analysis was conducted according to methods described by Shah et al. [17] and Wang et al. [18]. Briefly, $1 \mathrm{~g}$ of dried mushrooms and $10 \mathrm{~mL}$ of $0.25 \%$ TBA in $10 \%$ TCA were shaken in a rotary shaker for $30 \mathrm{~min}$ Then extract was centrifuged for $10 \mathrm{~min}$, at $9000 \mathrm{rpm}\left(4^{\circ} \mathrm{C}\right)$ and filtrated. Further, the extracted supernatant was incubated in a water bath at $100{ }^{\circ} \mathrm{C}$ for $30 \mathrm{~min}$ and quickly chilled (ice bath). Subsequently, the extract was diluted (1.25 mL extract: $1 \mathrm{~mL}$ water) and absorbance was measured at $600 \mathrm{~nm}, 532 \mathrm{~nm}$, and $450 \mathrm{~nm}$ against blank using a UV-VIS spectrophotometer. Results were expressed as $\mathrm{MDA} \mu \mathrm{mol} / \mathrm{g} \mathrm{dw}$.

\subsubsection{Ferric Reducing Antioxidant Power (FRAP)}

FRAP analysis was measured according to Belwal et al. [19] with some modifications. FRAP solution was prepared by mixing sodium acetate buffer ( $300 \mathrm{mM}, \mathrm{pH} 3.6)$, ferric chloride $(20 \mathrm{mM})$ and 2,4,6-Tri(2-pyridyl)-s-triazine $(10 \mathrm{mM}$ in $40 \mathrm{mM} \mathrm{HCl})$ in a ratio 10:1:1. The $40 \mu \mathrm{L}$ of extract was mixed in $2.960 \mathrm{~mL}$ of FRAP solution and incubated in the dark for $30 \mathrm{~min}$. The absorbance ( $593 \mathrm{~nm}$ ) was measured using a UV-VIS spectrophotometer. Results were expressed as $\mathrm{mg}$ of ascorbic acid equivalent per gram of dry weight. 


\subsubsection{DPPH Radical Scavenging Assay}

Analysis was performed with the usage of radical 2,2-diphenoyl-1-picrylhydrazyl (DPPH), according to the methodology of Belwal et al. [19] with some minor modifications. Briefly, $50 \mu \mathrm{L}$ of mushrooms extracts was added to 2.95 solution of DPPH and stirred. The absorbance was measured after incubated in dark place (30 min, room temperature) using UV-VIS spectrophotometer at $520 \mathrm{~nm}$. The obtained result was expressed as $\mathrm{mg}$ of ascorbic acid equivalent per gram of dry weight.

\subsubsection{E-Nose Analysis}

A Heracles II Electronic Nose (Alpha M.O.S., Toulouse, France) equipped with two columns, one polar (MXT-1701) and another non-polar (MXT-5), was used to study the volatile compounds profile of Agaricus bisporus. Mushrooms were cut into small cubes. Then, $1 \mathrm{~g}$ was put into a $20 \mathrm{~mL}$ glass vial and closed with a teflon-silicone rubber cap and the samples were incubated $\left(45^{\circ} \mathrm{C}, 10 \mathrm{~min}\right)$. After that, the autosampler injected gas $(3500 \mu \mathrm{L})$ into the columns from the headspace of samples. The parameters of analysis were set as follows: flame ionization detectors (FID) at $270{ }^{\circ} \mathrm{C}$, injector at $200^{\circ} \mathrm{C}$, oven temperature program at $60^{\circ} \mathrm{C}$ for $2 \mathrm{~s}$, a $3{ }^{\circ} \mathrm{C} \mathrm{s}^{-1} \mathrm{ramp}$ to $270{ }^{\circ} \mathrm{C}$, and isotherm at $270{ }^{\circ} \mathrm{C}$ for $30 \mathrm{~s}$. Kovats retention indexes were used to detect volatile compounds in the mushroom sample. Measurement was performed in nine replicates for each variant on storage day $(0$, $14,28)$.

\subsection{Statistical Analysis}

Statistical analysis was performed using STATISTICA software version 13.3 (StatSoft, Tulsa, OK, USA). Normality of the data distribution was checked by the Shapiro-Wilk test. One-way ANOVA followed by Tukey HSD test was used for verifying differences in both chemical and physical parameters. For multifactorial analysis, 95\%, 99\%, and 99.9\% confidence intervals were established, and in the case of one-way ANOVA 95\%. AlphaSoft Version 8.0 software was used for principal component analysis (PCA).

\section{Results and Discussion}

\subsection{Physical Quality Assessment of Agaricus bisporus \\ 3.1.1. Outer $\left(\mathrm{L}^{*} \mathrm{a}^{*} \mathrm{~b}^{*}\right)$ and Inner Color of Mushrooms}

The degree of consumer acceptability of A. bisporus depends mainly on its color and degree of browning [20]. White mushrooms are preferable to consumers. The color of mushrooms depends on many different factors both extrinsic and intrinsic. Extrinsic factors are: toxins, mechanical damage, and pathogen development which causes disruption of intracellular membranes. Intrinsic factors are enzymes reacting with substrates, e.g., tyrosinase catalyzes conversion of phenolic substrates into first stage substances which starts the synthesis of melanins [21,22]. Therefore, the measurement of $\mathrm{L}^{*}, \mathrm{BI}, \Delta \mathrm{E}$, and browning degree inside the mushroom cap is essential to estimate the marketing value of the mushrooms. Color parameters measured in A. bisporus packed with active packaging and stored in cold conditions for 28 days are presented in Figure 1. The $L^{*}$ parameter decreased during storage and ranged between 94.95 (fresh mushrooms, not packaged) and 89.93 (C, 28 day storage). Decreased values of lightness indicate darkening of mushrooms. This is also confirmed by the parameters $a^{*}$ and $b^{*}$ (data not shown), the value of which increased during storage. This proportion, yellow and red, reflects the browning process of the mushrooms [23]. Studies carried out by Liu \& Wang [24] and Gholami et al. [25] confirmed that the use of packaging in modified atmosphere significantly improved the lightness of the mushrooms after 21 days of storage. After 14 and 21 days of storage, there were no statistical differences in the $\Delta \mathrm{E}$ parameter between the $\mathrm{C}$ and the groups packed with the usage of active packaging. In turn, the differences were observed after 28 days of storage. Active packaging with the addition of FZ and FEZ reduced $\triangle \mathrm{E}$. Similar results were obtained for BI analysis, where active packaging with the addition of zeolite and extract compared to $C$ and PVC slowed down the browning process. For consumers, apart 
from the external color, the internal color is also important, because it responds to the perception of its freshness. Further, active packaging significantly improved the degree of browning measured inside mushrooms (Figure 1C). Zhang et al. [20] noted the positive effect of active packaging using a nano- $\mathrm{SiO}_{2} /$ glucomannan/carrageenan coating on both external color and internal darkening of the mushrooms during the storage. Moreover, the positive effect of green tea extract as an ingredient of active packaging on color change was also shown by Wrona et al. [26]. Furthermore, the examined mushrooms on day 28 had $\mathrm{L}>86$, which proves good quality of mushrooms [27]. Referring to the presented results, the use of active packaging containing $3 \%(w / v)$ of the açai extract and $1 \%(w / v)$ of zeolite had a noticeable positive effect in terms of reducing the color change, browning index, and internal browning of mushroom caps.
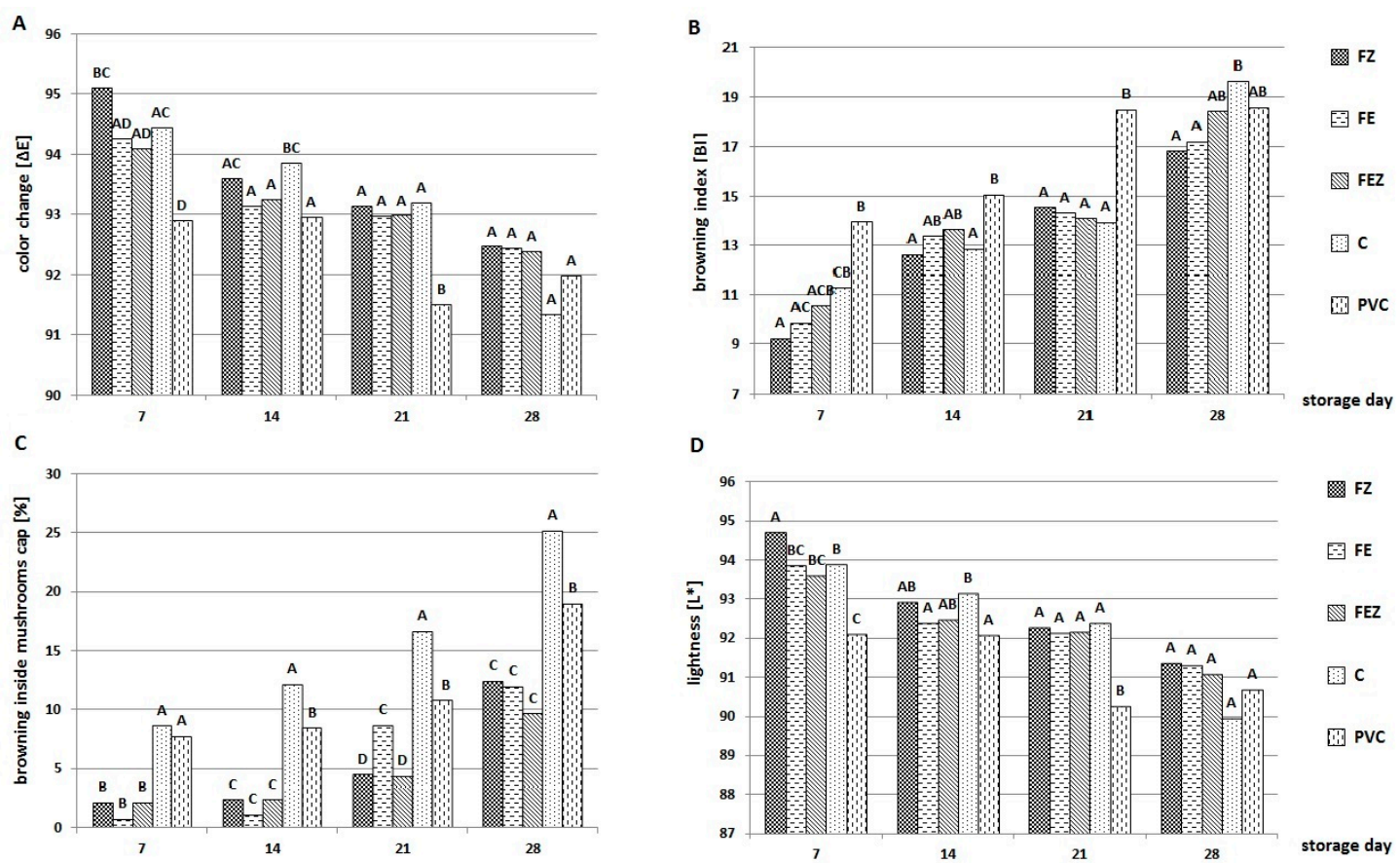

Figure 1. Color changes on the surface of the caps: color change (A), browning index (B), lightness (D) and browning degree inside mushroom caps (C) in different active packaging with zeolite (FZ), açai extract (FE), açai extract + zeolite (FEZ) packed in MAP, without active packaging in MAP (C) and wrapped in polyvinyl chloride foil (PVC) measured on each storage day. A, B, C-letters mark differences between packaging on the same storage day.

\subsubsection{Weight Loss and Texture}

Water loss is a very important physiological process which has an impact on the quality characteristics of mushrooms, such as texture, appearance, and weight, which in turn are responsible for its hardness [28]. In our research, weight loss increased linearly with each day of storage $(7,14,21,28)$ in all applied forms of packaging (Figure 2) and ranged from $0.15 \%$ (PVC, day 7 ) to $0.85 \%$ (control, day 28 ). Weight loss analysis of mushrooms from different active packages over the same storage period (day 28) showed a statistical difference between groups C and FE vs. PVC, FZ and FEZ. The low water loss in the case of PVC is caused probably due to its low perforation degree. The PVC is characterized by low water permeability $[29,30]$. We observed that, in the case of active packaging with açai extract + zeolite and zeolite $(0.5 \% w / v$ and $1 \% w / v)$ packed with perforated foil, there was no statistical differences in comparison to PVC foil on the last day of storage (day 28). The absorption properties of zeolite slowed down the water loss of mushrooms [31], which resulted in a decrease of relative humidity, which in turn inhibited saturation inside the package and water droplets formation. 


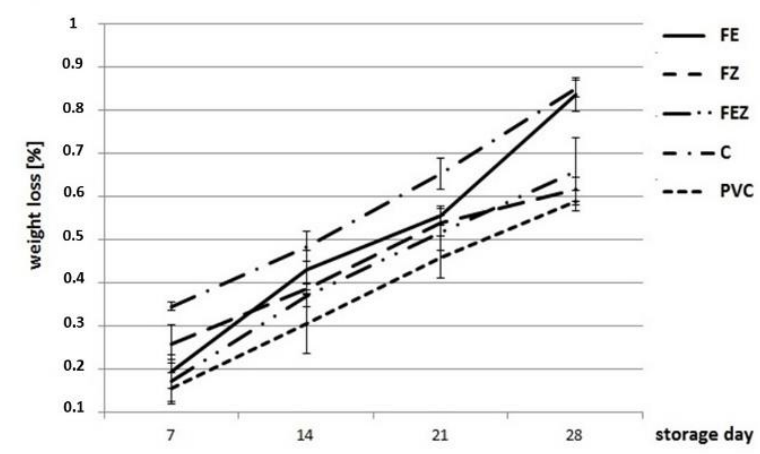

Figure 2. Weight loss of white button mushrooms packed in different active packages containing zeolite (FZ), açai extract (FE), açai extract + zeolite (FEZ) packed in MAP, without active packaging in MAP (C) or wrapped in polyvinyl chloride foil (PVC) measured on each storage day. Standard error is presented in a form of horizontal bars.

During storage, the physical characteristics of mushrooms, such as firmness, gumminess, chewiness, and elasticity, change. This determines the texture. In the presented study, the hardness decreased during storage regardless of the type of active packaging used (Table 1). Similar results were observed by Han et al. [32] and Cheng et al. [33]. These changes are related to the degradation of proteins and polysaccharides, water content and its migration, as well as changes in the permeability of the cell membrane [14,34]. The firmness of the examined mushrooms ranged from 14.33 [N] on day 0 to 8.07 [N] on the last day of storage (day 28). No statistical differences were observed on days 21 and 28 of storage, regardless of the type of active packaging used. These results may be caused by metabolic changes in mushrooms, which result in cell wall degradation, increased activity of endogenous autolysis, destruction of central vacuoles, as well as the reduction of lignin formation in the cell wall [35-37]. Nonetheless, other factors such as the composition of the gases in the space $\left(\mathrm{CO}_{2}\right.$ concentration) above the solution and the relative humidity can also affect the firmness of mushrooms [38].

Table 1. Texture (hardness) measured in mushroom caps packed with active packaging containing zeolite (FZ), açai extract (FE), açai extract + zeolite (FEZ) packed with MAP, without active packaging in MAP (C) and wrapped polyvinyl chloride foil (PVC) on each storage day. ${ }^{\mathrm{A}}$, ${ }^{\mathrm{B}}$-letters mark differences between every packaging variant on the same storage day.

\begin{tabular}{ccc}
\hline Storage Day & Type Active Packaging & Hardness [N] \\
\hline $\mathbf{0}$ & FM $^{*}$ & $\mathbf{1 4 . 3 3}$ \\
\hline & FZ & $12.41^{\mathrm{A}}$ \\
7 & FE & $12.86^{\mathrm{AB}}$ \\
& FEZ & $13.35^{\mathrm{AB}}$ \\
C & $13.25^{\mathrm{AB}}$ \\
& PVC & $13.83^{\mathrm{B}}$ \\
\hline & FZ & $12.14^{\mathrm{B}}$ \\
& FE & $10.94^{\mathrm{A}}$ \\
& FEZ & $11.19^{\mathrm{AB}}$ \\
& $\mathrm{C}$ & $11.27^{\mathrm{AB}}$ \\
& PVC & $12.14^{\mathrm{B}}$ \\
\hline & FZ & $9.66^{\mathrm{A}}$ \\
& FE & $9.83^{\mathrm{A}}$ \\
& FEZ & $10.02^{\mathrm{A}}$ \\
& $\mathrm{C}$ & $9.02^{\mathrm{A}}$ \\
& PVC & $9.29^{\mathrm{A}}$
\end{tabular}


Table 1. Cont.

\begin{tabular}{ccc}
\hline Storage Day & Type Active Packaging & Hardness [N] \\
\hline $\mathbf{0}$ & FM * & $\mathbf{1 4 . 3 3}$ \\
\hline & FZ & $9.26^{\mathrm{A}}$ \\
28 & FE & $9.90^{\mathrm{A}}$ \\
& FEZ & $9.71^{\mathrm{A}}$ \\
& C & $8.07^{\mathrm{A}}$ \\
& PVC & $8.43^{\mathrm{A}}$ \\
\hline
\end{tabular}

*FM-fresh mushrooms analyzed at day 0 (not packed mushrooms).

\subsubsection{Gas Composition}

During the harvest, mushrooms are cut off from water and nutrients, but the cap is still a living organ that carries out life processes, especially respiration, which is the main metabolic process [37]. Respiration rate and the permeability of the packaging film determine the gas composition inside the package [39]. Analyzing the headspace gas composition after active packaging and $\mathrm{MAP}$, the $\mathrm{O}_{2}$ concentration was $80 \%$ on day zero. In contrast, after seven days of storage, we observe a sudden decrease in $\mathrm{O}_{2}$ concentration inside the applied packing's (19\%), (data not shown). During the storage, the $\mathrm{O}_{2}$ concentration remained at a similar level $(19.43 \% \pm 0.90)$, which indicates that gas diffusion through the film compensated $\mathrm{O}_{2}$ consumption by white button mushrooms [25]. Nonetheless, final $\mathrm{O}_{2}$ concentration inside the package was $>5 \%$, which, according to Qin et al. [40], prevented anaerobic respiration in A. bisporus. In turn, the concentration of $\mathrm{CO}_{2}$ detected after 28 days of storage at $4{ }^{\circ} \mathrm{C}$ ranged between $1.9 \%$ to $3.2 \%$, regardless of the type of packaging used (data not shown). These results are consistent with the thesis formed by Joshi et al. [41] that the optimal conditions for storage of mushrooms at $2{ }^{\circ} \mathrm{C}$ should be $2.5-5 \% \mathrm{CO}_{2}$.

\subsection{Chemical Composition Analysis of Agaricus bisporus}

\subsubsection{Total Phenolic Compounds}

Mushrooms contain phenolic compounds, secondary metabolites which serves a dual function. Browning of mushrooms results from postharvest stress due to oxidation of phenolic compounds caused by polyphenol oxidase (PPO, EC1.10.3.1). On the other hand, phenols possess a strong antioxidant capacity that inhibits the oxidation chain reactions and thus they retard lipid peroxidation [42,43]. Changes in the TPC content of $A$. bisporus packed with active packages and stored for 28 days are shown in Figure 3. Total phenol content is increased on subsequent storage days in comparison to day 0. Analyzing the results of TPC obtained from mushrooms packed in MAP, an increase in the content of these compounds up to day 21 can be noted ( $3.73 \mathrm{mg}$ gallic acid $\mathrm{g}^{-1} \mathrm{dw}$ ), after which has occurred a significant decrease (3.42 $\mathrm{mg}$ gallic acid $\mathrm{g}^{-1} \mathrm{dw}$ ). Liu et al. [39] and Ding et al. [44] have observed similar trends in their studies. As a result of applying active packaging with zeolite (FZ) and packaging in MAP (C), a significant increase of TPC content in mushrooms after 21 days of storage has been measured $\left(3.61,3.73 \mathrm{mg}\right.$ gallic acid $\left.\mathrm{g}^{-1} \mathrm{dw}\right)$, whereas in groups packed in FE, FEZ, PVC was statistically lower (2.76-2.92 $\mathrm{mg}$ gallic acid $\mathrm{g}^{-1} \mathrm{dw}$ ). Pearson's correlation analysis (Table 2$)$ showed a positive correlation $(p \leq 0.001)$ between the content of polyphenols and browning index. This correlation confirms the relationship between the content of TPC, which are the main substrates in the browning process initiated by polyphenol oxidase (tyrosinase) and laccase [22,26], and the browning degree measured instrumentally. 
A
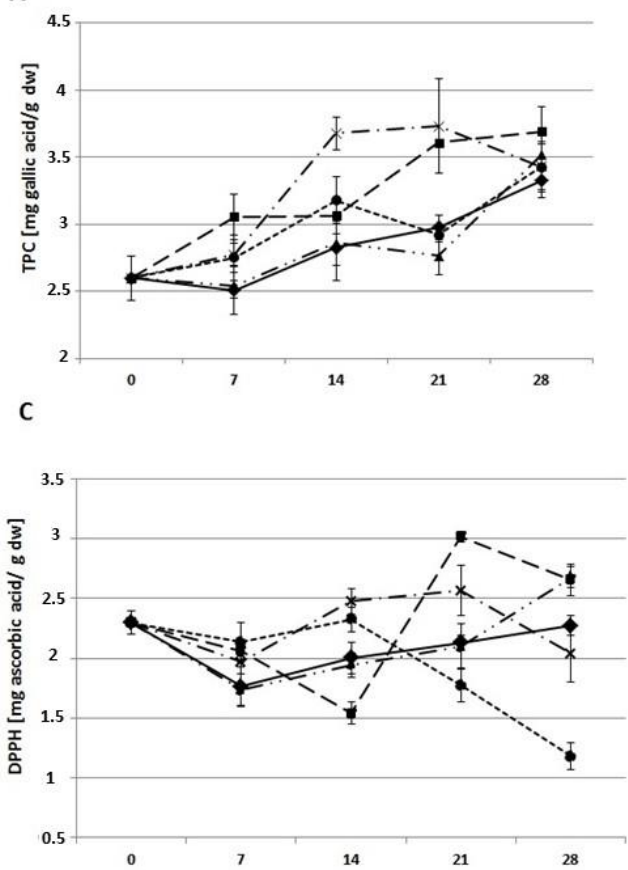
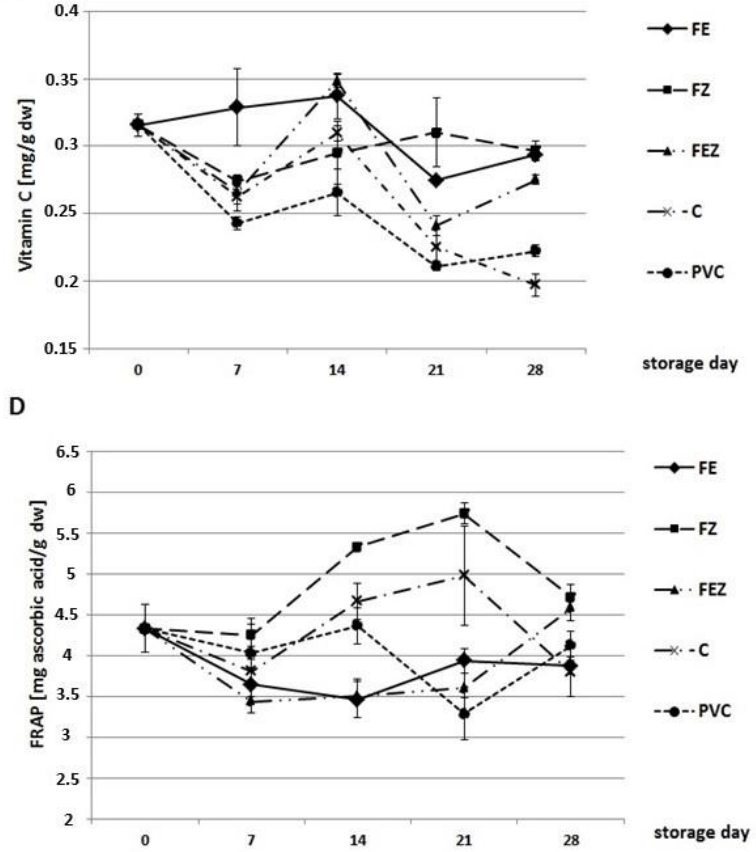

Figure 3. Total phenolic compounds (TPC) (A), Vitamin C (B) and antioxidant capacity DPPH (C) and FRAP (D) measured in Agaricus bisporus packed with active packages containing zeolite (FZ), açai extract (FE), açai extract + zeolite (FEZ) in MAP, without active packaging in MAP (C) and wrapped in polyvinyl chloride foil (PVC). Standard error is presented in a form of horizontal bars.

Table 2. Pearson's correlation coefficients of mushrooms quality parameters between total phenol (TPC), vitamin C (vit. C), malondialdehyde (MDA) contents, antioxidant activity (DPPH, FRAP), lightness $\left(\mathrm{L}^{*}\right)$, color change $(\Delta \mathrm{E})$, browning index (BI) and browning measured inside mushrooms cap (BIMC).

\begin{tabular}{|c|c|c|c|c|c|c|c|c|c|}
\hline & vit. C & MDA & DPPH & FRAP & TPC & $\mathbf{L}^{*}$ & $\Delta \mathrm{E}$ & BI & BIMC \\
\hline vit. C & 1.00 & -0.10 & 0.19 * & 0.11 & -0.11 & 0.07 & $-0.30^{* * *}$ & $-0.46^{* *}$ & -0.06 \\
\hline MDA & & 1.00 & 0.08 & -0.09 & 0.05 & -0.19 * & 0.16 & 0.03 & $0.22 *$ \\
\hline DPPH & & & 1.00 & $0.52^{* * *}$ & $0.55^{* * *}$ & $-0.43^{* * *}$ & -0.02 & $0.31^{* * *}$ & 0.05 \\
\hline FRAP & & & & 1.00 & $0.66^{* * *}$ & $-0.3^{* * *}$ & 0.14 & 0.11 & -0.21 * \\
\hline $\mathrm{TPC}$ & & & & & 1.00 & -0.12 & 0.13 & $0.36^{* * *}$ & -0.08 \\
\hline $\mathrm{L}^{*}$ & & & & & & 1.00 & 0.14 & $-0.22 *$ & -0.15 \\
\hline$\Delta \mathrm{E}$ & & & & & & & 1.00 & $0.46^{* * *}$ & 0.08 \\
\hline BI & & & & & & & & 1.00 & -0.11 \\
\hline BIMC & & & & & & & & & 1.00 \\
\hline
\end{tabular}

*** Significant at $p \leq 0.001,{ }^{* *}$ significant at $p \leq 0.01,{ }^{*}$ significant at $p \leq 0.05$.

\subsubsection{Vitamin C Content}

Literature shows that the mushrooms produce L-ascorbic acid, which is physiologically important as its synthesis occurs by at least three biosynthetic pathways [42]. Vitamin C content in mushrooms ranged from 0.197 to $0.337 \mathrm{mg}$ ascorbic acid $\mathrm{g}^{-1} \mathrm{dw}$ (Figure 2). The lowest values throughout the storage period were observed for PVC and C groups (0.211-0.265 mg ascorbic acid $\mathrm{g}^{-1} \mathrm{dw}$ ). Reduction of vitamin $C$ content during the storage was caused probably by both enzymatic oxidation reactions and oxidation processes initiated by reactive oxygen species $[45,46]$. Noticeable, slow increase of vitamin $C$ concentration in mushrooms packed in active packages with addition of zeolite can be associated with gradual release of compounds from zeolite [47]. The content of vitamin C after seven days of storage severely dropped in all groups with the exception of mushrooms packed with active packaging enriched with the açai extract. In this group, the content of vitamin C 
in mushrooms increased $(7,14$ storage day) compared to day zero. This phenomenon might support the hypothesis that signaling compounds can influence fruits/plants causing mild stress in cells, which induces a defense response by production secondary metabolites such as vitamin C [48-50]. The tendency of rapid decrease then slight increase and once again decrease until the 21st day of storage was observed in PVC, FEZ and C groups. A similar trend was presented by Gao et al. [42] who noted that the final content of vitamin $\mathrm{C}$ was lower than measured on day 0 . Correlation analysis (Table 2) showed that the degree of vitamin $C$ concentration was negatively correlated with color parameters $(\Delta \mathrm{E}$, $p \leq 0.001$ and BI, $p \leq 0.01$ ). This result is consistent with the hypothesis presented by Hsu et al. [51], that ascorbic acid is an inhibitor of enzymatic browning. Ascorbic acid reduces conversion of a o-quinone to a phenolic substrate. In contrast, a positive correlation was noticed for antioxidant activity DPPH $(p \leq 0.05)$. Vitamin $\mathrm{C}$ is generally considered to have a remarkable antioxidant property, because it acts as a donor of single hydrogen atoms and the radical anion monodehydroascorbate reacts predominantly with radicals $[52,53]$.

\subsubsection{Antioxidant Activity (DPPH and FRAP)}

Both DPPH and FRAP are well-known and widely used methods to assess the ability of molecules to neutralize free radicals. The FRAP measures the capacity of extracts to reduce ferric tripyridyltriazine complex to the ferrous form. In turn DPPH method is based on the free radical scavenging activity [54]. DPPH radical scavenging activity of $A$. bisporus was measured on days: 7, 14, 21, 28 of storage (Figure 3C). After seven days of storage in all groups, DPPH activity decreased. After 21 days, an upward trend of antioxidant activity was noticed for mushrooms packed in comparison to mushrooms wrapped with PVC film. Moreover, for PVC and C groups, the lowest antioxidant capacity was observed $\left(1.18,1.78 \mathrm{mg}\right.$ ascorbic acid $\mathrm{g}^{-1} \mathrm{dw}$, respectively) on day 28 of storage. This result indicates

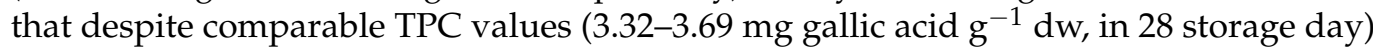
for every variant of packaging, the antioxidant capacity (DPPH) was significantly different. These differences may be due to the fact that each compound belonging to the phenolic group has different antioxidant properties or that the phenolic compounds have already used up their free radical scavenging potential $[55,56]$. Based on Pearson's correlation coefficients (Table 2 ) the positive relationship between antioxidant activity (DPPH) and Vitamin C content $(p \leq 0.05)$ and TPC content $(p \leq 0.001)$ was observed. The study by Bernaś et al. [57] also showed a positive correlation between antioxidant activity and TPC. On the one hand, the increased activity of the phenylpropanoid pathway leads to the synthesis of phenols, which are characterized by high antioxidant activity [24]. However, phenols are substrates for the PPO enzymatic reaction, which increases the dynamic of phenolic compounds conversion into quinones and next into melanin (dark pigment) [21]. The consequence of these changes is probably a negative correlation $(p \leq 0.001)$ of antioxidant activity $(\mathrm{DPPH})$ with lightness of mushrooms $\left(\mathrm{L}^{*}\right)$ and a positive correlation $(p \leq 0.001)$ with browning index (BI).

The antioxidant activity of $A$. bisporus measured by the FRAP method on day zero was $4.33 \mathrm{mg}$ of ascorbic acid $\mathrm{g}^{-1} \mathrm{dw}$, while through the storage ranged between 3.29 and $5.73 \mathrm{mg}$ of ascorbic acid $\mathrm{g}^{-1} \mathrm{dw}$ (Figure 3). A similar result as in the case of DPPH was obtained in the FRAP analysis, where the use of active packaging with the addition of zeolite (on day 28) resulted in a higher antioxidant activity (FRAP) compared to the other packaging variants. Interestingly, despite the different radicals present in the DPPH and FRAP analysis, Pearson correlation analysis (Table 2 ) showed a strong positive correlation $(p \leq 0.001)$ between antioxidant activities measured by both those methods. This dependence is confirmed by the study conducted by Ghahremi-Majd and Daskti [58]. The same correlation degree for DPPH is observed for FRAP in relation to TPC (positive correlation, $p \leq 0.001$ ) and $\mathrm{L}^{*}$ (negative correlation $p \leq 0.001$ ) content. This is probably due to an accumulation of a great number of phenolic compounds which are substrates for reactions of enzymatic browning [59]. 


\subsubsection{Malondialdehyde Content}

Lipid peroxidation of polyunsaturated fatty acids in cell membranes lead to the creation of many degradation products. Malondialdehyde (MDA) is considered to be a main product and biomarker of membrane lipid peroxidation. The accumulation of MDA can cause many adverse changes, e.g., loosen bridges in cellulose chains or through crosslinking nucleic acids and proteins can limit their biological functions [60]. The low MDA value (Figure 4) throughout the storage period in the case of active packaging with the addition of açai extract or açai extract + zeolite may be associated with presence of volatile compounds that may have antioxidant properties which could slow down the oxidation processes [61,62]. The content of MDA in A. bisporus after seven days of storage increased significantly compared to day zero regardless of the type of packaging. Those findings are in line with conclusions made by Zhang et al. [38]. After 14 days of storage, MDA content in PVC, FEZ, and FZ groups decreased, whereas for C and FE, it increased. In turn, on day 21 , the MDA content was lower compared to the previous week, in each group, except for PVC. The use of active packaging, either with an açai extract, zeolite, or a combination, resulted in lower accumulation of MDA compared to the C or PVC group. These changes may possibly be related to the lipid peroxidation mechanism. Generally, lipid peroxidation is a process during which free radicals (oxidants) attack lipids containing carbon double bonds, in particular polyunsaturated fatty acids. Linoleic acid is an unsaturated fatty acid which presents in A. bisporus to the greatest extent [63]. The products of lipid oxidation are mainly lipid hydroperoxides, nevertheless secondary products may form, such as: MDA, 4-hydroxynonenal (4-HNE), hexanal, isoprostanes or propanal through oxygen radicaldependent oxidative process. This process may proceed with different dynamics and lead to production of a mix of various lipid oxidation products. Thus, the MDA level by itself cannot give the full image of lipid oxidation in general. Thus, the drop of MDA content in experimental groups (except for PVC group) after 21 days of storage can testify that MDA level shows only a fraction image of the lipid oxidative status in tested samples [64].

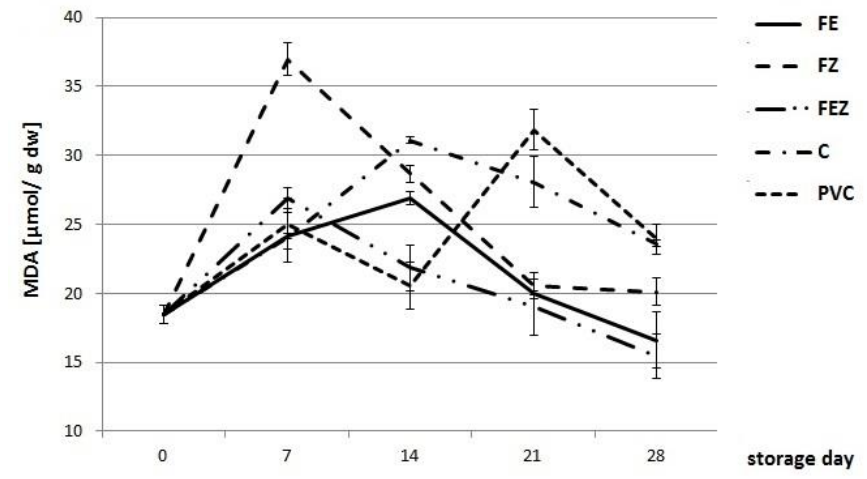

Figure 4. Malondialdehyde (MDA) content of white button mushrooms packed in different active packages containing zeolite (FZ), açai extract (FE), açai extract + zeolite (FEZ) packed in MAP, without active packaging in MAP (C) or wrapped in polyvinyl chloride foil (PVC) measured on each storage day. Standard error is presented in a form of horizontal bars.

\subsubsection{Volatile Compounds Analysis}

Volatile compounds in white button mushrooms characterize the degree of mushrooms development state, which is directly related to quality. Principal component analysis (PCA) was used to find the trend, which explicate the best variance in the date set (Figure 5). On day 14 of storage, more than $38 \%$ of total variance was explained by 1 st principal component (PC1), whereas the 2nd principal component (PC2) explained $22.78 \%$ of total variance, and 3rd principal (PC3) explained 7.39\% of the total variance. However, on day 28 , these differences increased, and they explained total variance in: $49.57 \%$ for PC1, $13 \%$ for PC2, and $8.11 \%$ for PC 3 . Volatile compounds identified in white button mushrooms was presented in Table 3. Nine compounds were detected in fresh mushrooms. 
With the storage time, the amount and type of volatile compounds detected in samples has changed. Compounds such as 1-propanol, 2,6,6-trimethylbicyclo[3.1.1]hept-2-ene ( $\alpha$ pinene) and decanol-2-one were identified after 14 days of storage in mushrooms from each group. Referring to volatile compounds identified after 28 days of storage, the compounds present in all experimental variants were: $\alpha$-pinene, 1 -propanol and butane2,3-dione. Differences and similarities may result from volatile compound formation mechanisms which run through metabolic changes from non-volatile compounds. Mainly amino acids and fatty acids take part in the process of volatile compound formation. Amino acids are reduced to alcohols through the following stages: amino acids $->$ alpha keto acids $->$ aldehydes $->$ alcohols [65]. In contrast, fatty acids, especially linoleic acid, subjected to the enzymatic reaction (lipoxygenase), are oxygenated to hydroperoxides. Those metabolic transformations are conditioned by many factors, e.g., genotype, storage conditions, developmental stage, and even some scarce volatile compounds may affect the physiological condition of mushrooms [66].
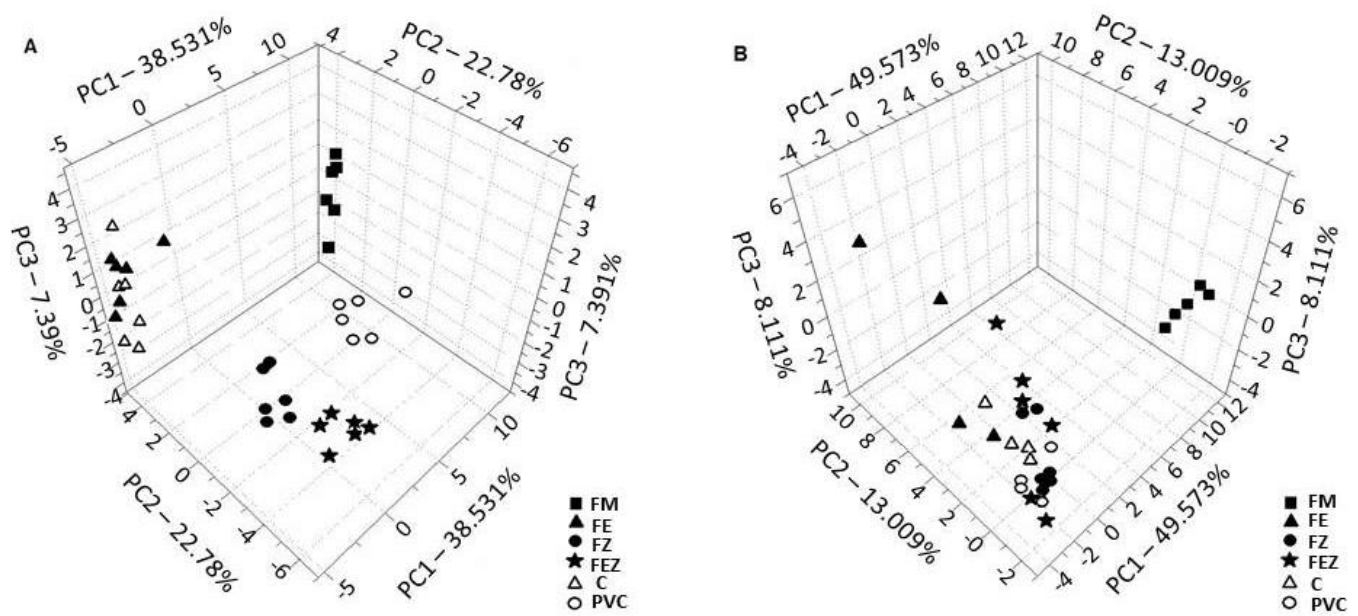

Figure 5. Analysis of principal components (PCA) of volatile compounds identified in mushrooms packed with active packaging containing zeolite (FZ), açai extract (FE), açai extract + zeolite (FEZ) in MAP, without active packaging in MAP (C) and wrapped in polyvinyl chloride foil (PVC) and analyzed in fresh mushrooms (FM, day 0), after 14 (A) and 28 (B) days of storage.

Table 3. Volatile compounds identified in mushrooms packed with active packaging containing zeolite (FZ), açai extract (FE), açai extract + zeolite (FEZ) in MAP, without active packaging in MAP (C), wrapped in polivynyl chloride foil (PVC) and fresh mushrooms (FM) after 0, 14 and 28 days of storage).

\begin{tabular}{|c|c|c|c|c|c|c|c|c|c|c|c|c|}
\hline \multirow{3}{*}{ Identified Volatile Compounds } & \multirow{3}{*}{$\begin{array}{c}\text { Sensory } \\
\text { Descriptors }\end{array}$} & \multicolumn{11}{|c|}{ Day of Storage } \\
\hline & & \multicolumn{3}{|l|}{0} & \multicolumn{3}{|c|}{14} & \multicolumn{5}{|c|}{28} \\
\hline & & FM & $\mathbf{E}$ & $\mathbf{Z}$ & EZ & C & PVC & $\mathbf{E}$ & $\mathbf{Z}$ & EZ & $\mathrm{C}$ & PVC \\
\hline \multicolumn{13}{|c|}{ aldehydes } \\
\hline 3,7-dimethyl-2,6-octadienal & citrus & + & + & + & & & & & & & & \\
\hline 2-methylpropanal & burnt & + & & & & & & & & & & \\
\hline 6-decanal & green & + & & & & & & & & & & \\
\hline butanal & chocolate & & & + & + & & + & & & & & \\
\hline \multicolumn{13}{|c|}{ alcohols } \\
\hline 1-propanol & alkoholic & & + & + & + & + & + & + & + & + & + & + \\
\hline nonan-3-ol & herbiceous & + & & & & & & & & & & \\
\hline 4-methylhexan-1-ol & grassy & + & + & & & & & & & & & \\
\hline butan-1-ol & cheese & & & & & + & & & & & & \\
\hline propane-1,2-diol & carmelized & & & & & & + & & + & + & & \\
\hline 2-methyl-5-prop-1-en-2-ylcyclohex-2-en-1-ol & caraway & + & & & & & & + & & & + & + \\
\hline
\end{tabular}


Table 3. Cont.

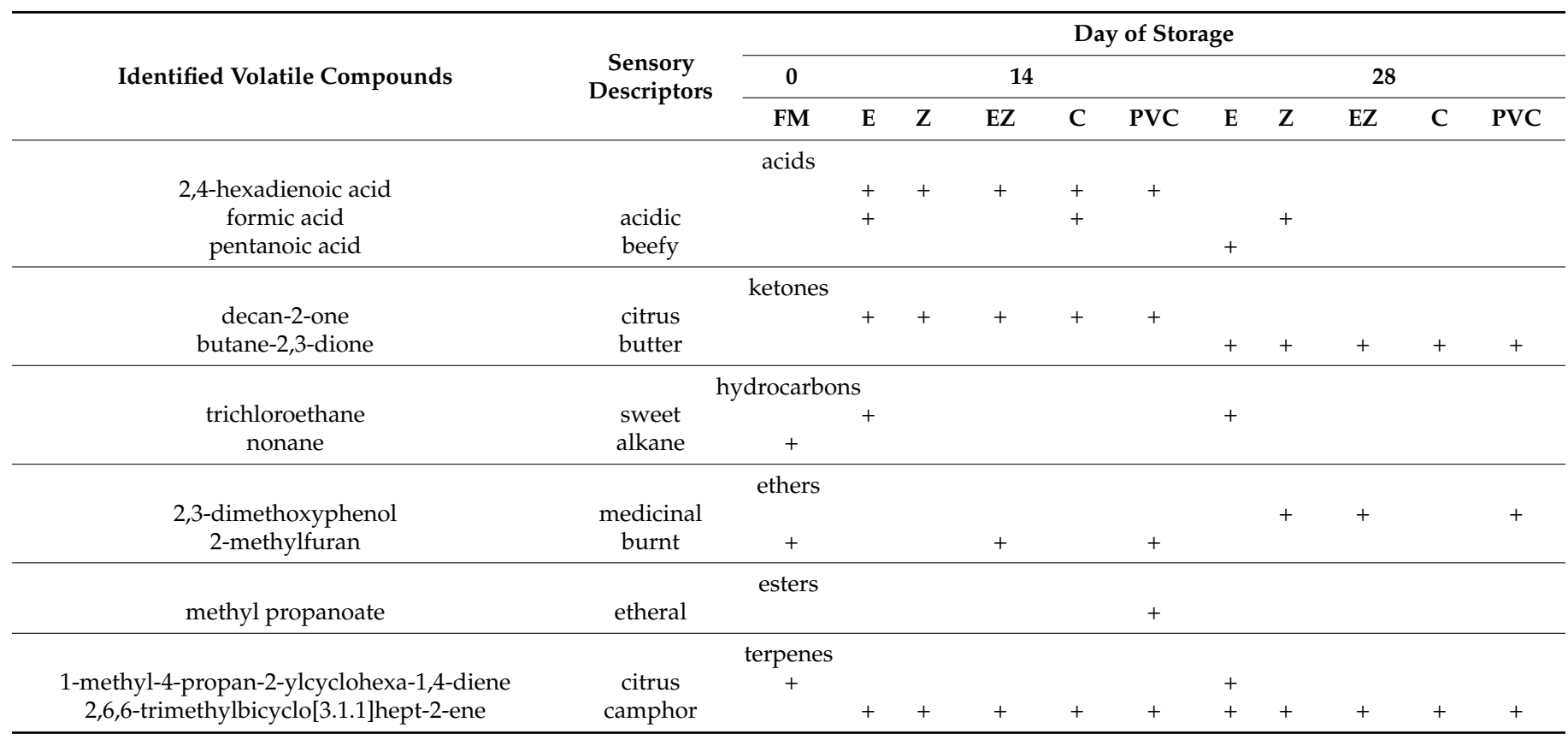

\section{Conclusions}

This research was carried out in order to verify if active packaging with the addition of zeolite (clinoptilolite) and açai extract can increase the shelf life of $A$. bisporus. The obtained results indicate that the use of active packaging primarily decreased water loss and slowed down the browning process both outside and inside the mushrooms. Moreover, mushrooms stored in active packaging, especially with added zeolite, were characterized by a higher content of vitamin $C$ and antioxidant activity compared with the $C$ and PVC groups. Furthermore, the study showed a high correlation $(p \leq 0.001)$ between color parameters $\left(\mathrm{L}^{*}, \Delta \mathrm{E}\right.$, and $\left.\mathrm{BI}\right)$, content of bioactive compounds (TPC and vitamin $\mathrm{C}$ ), and antioxidant activity (DPPH, FRAP). In summary, active packaging enriched with acai extract and zeolite may effectively inhibit the deterioration of mushroom quality (physical and chemical) when stored after harvest at $4{ }^{\circ} \mathrm{C}$ for 28 days.

Author Contributions: M.H.: Conceptualization, formal analysis, investigation, methodology, supervision, roles/writing — original draft, visualization. E.P.-N.: Formal analysis, investigation, methodology, supervision, writing—review \& editing. G.P.: Methodology. A.S.: Methodology. I.W.-K.: Methodology. A.W.: Writing—review \& editing. A.P.: Funding acquisition, supervision. All authors have read and agreed to the published version of the manuscript.

Funding: This research was funded by Polish Ministry of Science and Higher Education within funds of Institute of Human Nutrition Sciences, Department of Technique and Food Product Development, Warsaw University of Life Sciences (WULS-SGGW), for scientific research.

Acknowledgments: The authors would like to acknowledge Roman J. Jẹdrzejczyk (Małopolska Centre of Biotechnology, Jagiellonian University in Kraków) for technical support.

Conflicts of Interest: The authors declare no conflict of interest.

\section{References}

1. Barrera, E.L.; Hertel, T. Global food waste across the income spectrum: Implications for food prices, production and resource use. Food Policy 2021, 98, 101874. [CrossRef]

2. Filimonau, V.; Nghiem, V.N.; Wang, L. Food waste management in ethnic food restaurants. Int. J. Hosp. Manag. 2021, $92,102731$. [CrossRef]

3. Lin, Z.; Goddard, J. Photo-Curable Metal-Chelating Coatings Offer a Scalable Approach to Production of Antioxidant Active Packaging. J. Food Sci. 2018, 83, 367-376. [CrossRef] 
4. European Commission. Commission Regulation (EC) No 450/2009 of 29 May 2009 on active and intelligent materials and articles intended to come into contact with food. Off. J. Eur. Union 2009, 135, 3-11.

5. Omerović, N.; Djisalov, M.; Živojević, K.; Mladenović, M.; Vunduk, J.; Milenković, I.; Knežević, N.Ž.; Gadjanski, I.; Vidić, J. Antimicrobial nanoparticles and biodegradable polymer composites for active food packaging applications. Compr. Rev. Food Sci. Food Saf. 2021, 20, 2428-2454. [CrossRef] [PubMed]

6. Eroglu, N.; Emekci, M.; Athanassiou, C.G. Applications of natural zeolites on agriculture and food production. J. Sci. Food Agric. 2017, 97, 3487-3499. [CrossRef] [PubMed]

7. Yildirim, S.; Röcker, B.; Pettersen, M.K.; Nilsen-Nygaard, J.; Ayhan, Z.; Rutkaite, R.; Radusin, T.; Suminska, P.; Marcos, B.; Coma, V. Active Packaging Applications for Food. Compr. Rev. Food Sci. F. 2017, 17, 165-199. [CrossRef]

8. Lim, S.-H.; Nam, H.; Baek, H.-H. Aroma Characteristics of Acai Berry. Korean J. Food Sci. Technol. 2016, 48, 122-127. [CrossRef]

9. Earling, M.; Beadle, T.; Niemeyer, E.D. Açai Berry (Euterpe oleracea) Dietary Supplements: Variations in Anthocyanin and Flavonoid Concentrations, Phenolic Contents, and Antioxidant Properties. Plant Foods Hum. Nutr. 2019, 74, 421-429. [CrossRef] [PubMed]

10. Hanula, M.; Wyrwisz, J.; Moczkowska, M.; Horbańczuk, O.K.; Pogorzelska-Nowicka, E.; Wierzbicka, A. Optimization of Microwave and Ultrasound Extraction Methods of Açai Berries in Terms of Highest Content of Phenolic Compounds and Antioxidant Activity. J. Appl. Sci. 2020, 10, 8325. [CrossRef]

11. Siwulski, M.; Budka, A.; Rzymski, P.; Gąsecka, M.; Kalač, P.; Budzyńska, S.; Magdziak, Z.; Niedzielski, P.; Mleczek, P.; Mleczek, M. Worldwide basket survey of multielemental composition of white button mushroom Agaricus bisporus. Chemosphere 2020, 239, 124718. [CrossRef]

12. Muszyńska, B.; Piotrowska, J.; Krakowska, A.; Gruba, A.; Kała, K.; Sułkowska-Ziaja, K.; Kryczyk, A.; Opoka, W. Study of physiologically active components in different parts of fruiting bodies of varieties of Agaricus bisporus (white mushroom). Eur. Food Res. Technol. 2017, 243, 2135-2145. [CrossRef]

13. Mushroom Cultivation Market. Mushroom Cultivation Market by Type (Button Mushroom, Oyster Mushroom, Shiitake Mushroom, Other Types), By Phase, By Region (North America, Europe, Asia Pacific, South America, Rest of the World)—Global Forecast to 2025. Report 2020. pp. 1-141. Available online: https:/ / www.researchandmarkets.com/reports/5018601 (accessed on 7 June 2021).

14. Djekic, I.; Vunduk, J.; Tomašević, I.; Kozarski, M.; Petrovic, P.; Niksic, M.; Pudja, P.; Klaus, A. Total quality index of Agaricus bisporus mushrooms packed in modified atmosphere. J. Sci. Food Agric. 2016, 97, 2675-2680. [CrossRef]

15. Singleton, V.L.; Rossi, J.A. Colorimetry of Total Phenolics with Phosphomolybdic-Phosphotungstic Acid Reagents. Am. J. Enol. Vitic. 1965, 16, 144-158.

16. Balogh, T.; Szarka, A. A comparative study: Methods for the determination of ascorbic acid in small and middle sized food analytic laboratories. Acta Aliment. 2016, 45, 354-362. [CrossRef]

17. Shah, K.; Kumar, R.G.; Verma, S.; Dubey, R. Effect of cadmium on lipid peroxidation, superoxide anion generation and activities of antioxidant enzymes in growing rice seedlings. Plant Sci. 2001, 161, 1135-1144. [CrossRef]

18. Wang, Q.; Chu, L.; Kou, L. UV-C Treatment maintains quality and delays senescence of oyster mushroom (Pleurotus ostreatus). Sci. Hortic. 2017, 225, 380-385. [CrossRef]

19. Belwal, T.; Dhyani, P.; Bhatt, I.D.; Rawal, R.S.; Pande, V. Optimization extraction conditions for improving phenolic content and antioxidant activity in Berberis asiatica fruits using response surface methodology (RSM). Food Chem. 2016, 207, 115-124. [CrossRef]

20. Zhang, R.; Wang, X.; Li, L.; Cheng, M.; Zhang, L. Optimization of konjac glucomannan/carrageenan/nano-SiO2 coatings for extending the shelf-life of Agaricus bisporus. Int. J. Biol. Macromol. 2019, 122, 857-865. [CrossRef]

21. Zhang, K.; Pu, Y.-Y.; Sun, D.-W. Recent advances in quality preservation of postharvest mushrooms (Agaricus bisporus): A review. Trends Food Sci. Tech. 2018, 78, 72-82. [CrossRef]

22. Lin, X.; Sun, D.-W. Research advances in browning of button mushroom (Agaricus bisporus): Affecting factors and controlling methods. Trends Food Sci. Tech. 2019, 90, 63-75. [CrossRef]

23. Walkowiak-Tomczak, D.; Idaszewska, N.; Bieńczak, K.; Kómoch, W. The Effect of Mechanical Actions Occurring during Transport on Physicochemical Changes in Agaricus bisporus Mushrooms. Sustainability 2020, 12, 4993. [CrossRef]

24. Liu, Z.; Wang, X. Changes in color, antioxidant, and free radical scavenging enzyme activity of mushrooms under high oxygen modified atmospheres. Postharvest Biol. Tec. 2012, 69, 1-6. [CrossRef]

25. Gholami, R.; Ahmadi, E.; Farris, S. Shelf life extension of white mushrooms (Agaricus bisporus) by low temperatures conditioning, modified atmosphere, and nanocomposite packaging material. Food Packag. Shelf Life 2017, 14, 88-95. [CrossRef]

26. Wrona, M.; Bentayeb, K.; Nerín, C. A novel active packaging for extending the shelf-life of fresh mushrooms (Agaricus bisporus). Food Control 2015, 54, 200-207. [CrossRef]

27. Gormley, R. Chill storage of mushrooms. J. Sci. Food Agric. 1975, 26, 401-411. [CrossRef]

28. Shekari, A.; Hassani, R.N.; Aghdam, M.S.; Rezaee, M.; Jannatizadeh, A. The effects of melatonin treatment on cap browning and biochemical attributes of Agaricus bisporus during low temperature storage. Food Chem. 2021, 348, 129074. [CrossRef] [PubMed]

29. Pogorzelska-Nowicka, E.; Hanula, M.; Wojtasik-Kalinowska, I.; Stelmasiak, A.; Zalewska, M.; Półtorak, A.; Wierzbicka, A Packaging in a High O2 or Air Atmospheres and in Microperforated Films Effects on Quality of Button Mushrooms Stored at Room Temperature. Agriculture 2020, 10, 479. [CrossRef] 
30. Oz, A.T.; Ulukanlı, Z.; Bozok, F.; Baktemur, G. The postharvest quality, sensory and shelf life of Agaricus bisporus in active map. J. Food Process Pres. 2015, 39, 100-106. [CrossRef]

31. Nagrockiene, D.; Girskas, G. Research into the properties of concrete modified with natural zeolite addition. Constr. Build. Mater. 2016, 113, 964-969. [CrossRef]

32. Han, L.; Qin, Y.; Liu, D.; Chen, H.; Li, H.; Yuan, M. Evaluation of biodegradable film packaging to improve the shelf-life of Boletus edulis wild edible mushrooms. Innov. Food Sci. Emerg. Technol. 2015, 29, 288-294. [CrossRef]

33. Cheng, M.; Wang, J.; Zhang, R.; Kong, R.; Lu, W.; Wang, X. Characterization and application of the microencapsulated carvacrol/sodium alginate films as food packaging materials. Int. J. Biol. Macromol. 2019, 141, 259-267. [CrossRef]

34. Ghasemi-Vernamkhasti, M.; Mohammad-Razdari, A.; Yoosefian, S.H.; Izadi, Z. Effects of the combination of gamma irradiation and Ag nanoparticles polyethylene films on the quality of fresh bottom mushroom (Agaricus bisporus L.). J. Food Process. Pres. 2018, 42, e13652. [CrossRef]

35. Antmann, G.; Ares, G.; Lema, P.; Lareo, C. Influence of modified atmosphere packaging on sensory quality of shiitake mushrooms. Postharvest Biol. Technol. 2008, 49, 164-170. [CrossRef]

36. Singh, S.; Gaikwad, K.K.; Lee, M.; Lee, Y.S. Thermally buffered corrugated packaging for preserving the postharvest freshness of mushrooms (Agaricus bispours). J. Food Eng. 2018, 216, 11-19. [CrossRef]

37. Zhang, L.; Liu, Z.; Sun, Y.; Wang, X.; Li, L. Combined antioxidant and sensory effects of active chitosan/zein film containing $\alpha$-tocopherol on Agaricus bisporus. Food Packag. Shelf Life 2020, 24, 100470. [CrossRef]

38. Salamat, R.; Ghassemzadeh, H.R.; Ranjbar, F.; Jalali, A.; Mahajan, P.; Herppich, W.B.; Mellmann, J. The effect of additional packaging barrier, air moment and cooling rate on quality parameters of button mushroom (Agaricus bisporus). Food Packag. Shelf Life 2020, 23, 100448. [CrossRef]

39. Liu, J.; Liu, S.; Zhang, X.; Kan, J.; Jin, C. Effect of gallic acid grafted chitosan film packaging on the postharvest quality of white button mushroom (Agaricus bisporus). Postharvest Biol. Technol. 2019, 147, 39-47. [CrossRef]

40. Qin, Y.; Liu, D.; Wu, Y.; Yuan, M.; Li, L.; Yang, J. Effect of PLA/PCL/cinnamaldehyde antimicrobial packaging on physicochemical and microbial quality of button mushroom (Agaricus bisporus). Postharvest Biol. Technol. 2015, 99, 73-79. [CrossRef]

41. Joshi, K.; Warby, J.; Velverde, J.; Tiwari, B.; Cullen, P.J.; Frias, J.M. Impact of cold chain and product variability on quality attributes of modified atmosphere packed mushrooms (Agaricus bisporus) throughout distribution. J. Food Eng. 2018, 232, 44-55. [CrossRef]

42. Gao, M.; Feng, L.; Jiang, T. Browning inhibition and quality preservation of button mushroom (Agaricus bisporus) by essential oils fumigation treatment. Food Chem. 2014, 149, 107-113. [CrossRef]

43. Dokhanieh, A.Y.; Aghdam, M.S. Postharvest browning alleviation of Agaricus bisporus using salicylic acid treatment. Sci. Hortic. 2016, 207, 146-151. [CrossRef]

44. Ding, Y.; Zhu, Z.; Zhao, J.; Nie, Y.; Zhang, Y.; Sheng, J.; Meng, D.; Mao, H.; Tang, X. Effects of Postharvest Brassinolide Treatment on the Metabolism of White Button Mushroom (Agaricus bisporus) in Relation to Development of Browning During Storage. Food Bioproc. Technol. 2016, 9, 1327-1334. [CrossRef]

45. Vunduk, J.; Kozarski, M.; Djekic, I.; Tomašević, I.; Klaus, A. Effect of modified atmosphere packaging on selected functional characteristics of Agaricus bisporus. Eur. Food Res. Technol. 2021, 247, 829-838. [CrossRef]

46. Ojeda, G.A.; Sgroppo, S.C.; Martín-Belloso, O.; Soliva-Fortuny, R. Chitosan/tripolyphosphate nanoaggregates enhance the antibrowning effect of ascorbic acid on mushroom slices. Postharvest Biol. Technol. 2019, 156, 110934. [CrossRef]

47. Servatan, M.; Zarrintaj, P.; Mahmodi, G.; Kim, S.-J.; Ganjali, M.R.; Saeb, M.R.; Mozafari, M. Zeolites in drug delivery: Progress, challenges and opportunities. Drug Discov. Today 2020, 25, 642-656. [CrossRef]

48. Montero-Prado, P.; Bentayeb, K.; Nerín, C. Pattern recognition of peach cultivars (Prunus persica L.) from their volatile components. Food Chem. 2013, 138, 724-731. [CrossRef]

49. Gutiérrez, L.; Batlle, R.; Sánchez, C.; Nerín, C. New Approach to Study the Mechanism of Antimicrobial Protection of an Active. Packaging. Foodborne Pathog. Dis. 2010, 7, 1063-1069. [CrossRef] [PubMed]

50. Tokarz, K.M.; Makowski, W.; Tokarz, B.; Hanula, M.; Sitek, E.; Muszyńska, E.; Jędrzejczyk, R.; Banasiuk, R.; Chajec, Ł.; Mazur, S. Can Ceylon Leadwort (Plumbago zeylanica L.) Acclimate to Lead Toxicity?-Studies of Photosynthetic Apparatus Efficiency. Int. J. Mol. Sci. 2020, 21, 1866. [CrossRef]

51. Hsu, A.F.; Shieh, J.J.; Bills, D.D.; White, K. Inhibition of Mushroom Polyphenoloxidase by Ascorbic Acid Derivatives. J. Food Sci. 1988, 53, 765-767. [CrossRef]

52. Janani, N.; Zare, E.N.; Salimi, F.; Makvandi, P. Antibacterial tragacanth gum-based nanocomposite films carrying ascorbic acid antioxidant for bioactive food packaging. Carbohydr. Polym. 2020, 247, 116678. [CrossRef]

53. Njus, D.; Kelly, P.M.; Tu, Y.-J.; Schlegel, B. Ascorbic acid: The chemistry underlying its antioxidant properties. Free Radic. Biol. Med. 2020, 159, 37-43. [CrossRef]

54. Lin, Q.; Lu, Y.; Zhang, J.; Liu, W.; Guan, W.; Wang, Z. Effects of high $\mathrm{CO}_{2}$ in-package treatment on flavor, quality and antioxidant activity of button mushroom (Agaricus bisporus) during postharvest storage. Postharvest Biol. Technol. 2017, 123, 112-118. [CrossRef]

55. Huyut, Z.; Beydemir, Ş.B.; Gülçin, İ. Antioxidant and Antiradical Properties of Selected Flavonoids and Phenolic Compounds. Biochem. Res. Int. 2017, 2017, 7616791. [CrossRef]

56. Chen, J.; Yang, J.; Ma, L.; Li, J.; Shahzad, N.; Kim, C.K. Structure-antioxidant activity relationship of methoxy, phenolic hydroxyl, and carboxylic acid groups of phenolic acids. Sci. Rep. 2020, 10, 2611. [CrossRef] [PubMed] 
57. Bernaś, E. Comparison of the mechanism of enzymatic browning in frozen white and brown A. bisporus. Eur. Food Res. Technol. 2018, 244, 1239-1248. [CrossRef]

58. Ghahremani-Majd, H.; Dashti, F. Chemical Composition and Antioxidant Properties of Cultivated Button Mushrooms (Agaricus bisporus). Hort. Environ. Biotechnol. 2015, 56, 376-382. [CrossRef]

59. Wu, X.; Guan, W.; Yan, R.; Lei, J.; Xu, L.; Wang, Z. Effects of UV-C on antioxidant activity, total phenolics and main phenolic compounds of the melanin biosynthesis pathway in different tissues of button mushroom. Postharvest Biol. Technol. 2016, 118, 51-58. [CrossRef]

60. Hu, Y.-H.; Chen, C.-M.; Xu, L.; Cui, Y.; Yu, X.-Y.; Gao, H.-J.; Wang, Q.; Liu, K.; Shi, Y.; Chen, Q.-X. Postharvest application of 4-methoxy cinnamic acid for extending the shelf life of mushroom (Agaricus bisporus). Postharvest Biol. Technol. 2015, $104,33-41$. [CrossRef]

61. Saw, A.K.-C.; Yam, W.; Wong, K.-C.; Lai, C. A Comparative Study of the Volatile Constituents of Southeast Asian Coffea arabica, Coffea liberica and Coffea robusta Green Beans and their Antioxidant Activities. J. Essent. Oil Bear. Plants 2015, 18, 64-73. [CrossRef]

62. Moczkowska, M.; Karp, S.; Horbanczuk, O.K.; Hanula, M.; Wyrwisz, J.; Kurek, M.A. Effect of rosemary extract addition on oxidative stability and quality of hemp seed oil. Food Bioprod. Process. 2020, 124, 33-47. [CrossRef]

63. Nasiri, F.; Tarzi, B.G.; Bassiri, A.R.; Hoseini, S.E.; Aminafshar, M. Comparative Study on the Main Chemical Composition of Button Mushroom's (Agaricus bisporus) Cap and Stipe. J. Food Biosci. Technol. 2013, 3, 41-48.

64. Ayala, A.; Muñoz, M.F.; Argüelles, S. Lipid Peroxidation: Production, Metabolism, and Signaling Mechanisms of Malondialdehyde and 4-Hydroxy-2-Nonenal. Oxid. Med. Cell. Longev. 2014, 2014, 360438. [CrossRef]

65. Vahdatzadeh, M.; Splivallo, R. Improving truffle mycelium flavour through strain selection targeting volatiles of the Ehrlich pathway. Sci. Rep. 2018, 8, 9304. [CrossRef]

66. Feng, T.; Yang, M.; Ma, B.; Zhao, Y.; Zhuang, H.; Zhang, J.; Chen, D. Volatile profiles of two genotype Agaricus bisporus species at different growth stages. Food Res. Int. 2020, 140, 109761. [CrossRef] 